\title{
Androgen receptor corepressors and prostate cancer
}

\author{
Craig J Burd ${ }^{1}$, Lisa M Morey ${ }^{1}$ and Karen E Knudsen ${ }^{1,2,3}$
}

${ }^{1}$ Departments of Cell Biology, ${ }^{2}$ Center for Environmental Genetics, and ${ }^{3} \mathrm{UC}$ Cancer Center, University of Cincinnati College of Medicine, Cincinnati, Ohio 45267-0521, USA

(Requests for offprints should be addressed to K E Knudsen; Email: karen.knudsen@uc.edu)

\begin{abstract}
The androgen receptor (AR) mediates the effects of male steroid hormones (androgens) and contributes to a wide variety of physiological and pathophysiological conditions. As such, the regulatory mechanisms governing $A R$ activity are of high significance. Concerted effort has been placed on delineating the mechanisms that control AR activity in prostate cancer, as AR is required for survival and proliferation in this tumor type. Moreover, AR is the central therapeutic target for metastatic prostate cancers, and recurrent tumors evade therapy by restoring AR activity. It is increasingly apparent that $A R$ cofactors which modulate receptor activity can contribute to prostate cancer growth or progression, and this has been particularly well established for AR coactivators. The present review is focused on the role of AR corepressors in governing androgen action, with a specific emphasis on their activities in prostate cancer.
\end{abstract}

Endocrine-Related Cancer (2006) 13 979-994

\section{Introduction}

Androgens regulate numerous physiological responses from male sexual development to bone and muscle growth. The biological action of androgens is mediated through the androgen receptor (AR), a ligand-dependent transcription factor that belongs to the nuclear receptor superfamily (Trapman \& Brinkmann 1996). There is no sexually dimorphic organ, including the brain, which is not affected by AR during development. A large number of spontaneous mutations have been characterized that affect a broad range of phenotypes of male developmental abnormalities, including androgen insensitivity syndrome and spinal and bulbar muscular atrophy. AR is also necessary for the development of pathologic conditions later in life, most notably prostate cancer.

Prostatic adenocarcinoma is the most commonly diagnosed malignancy and the second leading cause of male cancer death in most western countries, including the United States (Denmeade \& Isaacs 2002, Jemal et al. 2006). Remarkably, prostate cancer development and progression are dependent upon AR function (Trapman \& Brinkmann 1996, Taplin \& Balk 2004), and first-line treatment for metastatic (including micrometastatic) disease is designed to specifically inhibit AR activity (Feldman \& Feldman 2001, Denmeade \& Isaacs 2002). These treatment regimens are accomplished through either depletion of ligand (testosterone) and/or through the use of antagonists that bind directly to AR (Denmeade \& Isaacs 2002, Salesi et al. 2005). Both intervention strategies are highly effective at reducing AR function, thereby inducing both cell cycle arrest and apoptosis in AR-dependent prostate cancer cells (Denmeade et al. 1996, Agus et al. 1999). However, recurrent tumors ultimately arise for which treatment efficacy is limited. Clinical analyses of recurrent tumors and recapitulation of therapeutic resistance in model systems strongly support the hypothesis that aberrant AR reactivation is responsible for tumor recurrence despite hormonal blockade (Feldman \& Feldman 2001). Given the importance of AR activity for prostate cancer development, growth, and progression, a concerted effort has been put forth to delineate the factors that regulate AR activity.

\section{Androgen receptor activation}

Androgens activate AR by unmasking its ability to bind DNA and thereby activate gene transcription. The AR belongs to the steroid receptor subclass of nuclear receptors, all ligand-activated transcription factors which bind to specific DNA sequences and transactivate a distinct subset of genes (Evans 1988, 
Mangelsdorf et al. 1995, Gelmann 2002). The AR protein is comprised of four domains: (i) an N-terminal domain (NTD) with the principle transcriptional activation functions (AF-1 and AF-5), (ii) a central DNA-binding domain (DBD), (iii) a hinge region, and (iv) a C-terminal ligand-binding domain flanked at the far C-terminus by another transcriptional activation function domain (AF-2; Jenster et al. 1992, Brinkmann et al. 1999). A nuclear import sequence flanks the DNA-binding and hinge regions. Like all nuclear steroid receptors, the AR is activated by ligand binding (Wilson 1996, Jenster 1999). Testosterone, secreted by both the testes and the adrenal gland, is the most abundant androgen and ligand for the AR present in the human male circulation. In target tissues, such as the prostate, testosterone is converted to dihydrotestosterone (DHT), through the action of $5 \alpha$-reductase. DHT is a high-affinity ligand for the AR, and although present at lower levels than testosterone, DHT is a much more powerful AR agonist (He et al. 2006). Prior to activation by ligand (DHT), the AR is present diffusely throughout the cytoplasm and nucleus of prostatic epithelial and adenocarcinoma cells. The inactive receptor is associated with heat-shock proteins that sequester AR in the cytoplasm and prevent the AR from exerting transcriptional activity (Marivoet et al. 1992). Upon ligand binding, the receptor dissociates from the heat-shock proteins and translocates to the nucleus (Jenster et al. 1993, Zhou et al. 1994). Active AR homodimers recognize and bind specific DNA sequences called 'androgen-response elements' (AREs), which are located in the promoter and/or enhancer region of androgen-responsive genes (Trapman \& Brinkmann 1996) and can be organized into either spaced palindromic or direct repeats (Verrijdt et al. 2003). Subsequent recruitment of cofactors regulates the ability of the AR to stimulate transcription of these target genes (Jenster 1998, Heinlein \& Chang 2002).

\section{AR coactivators in prostate cancer}

It is evident that ligand-induced cofactor recruitment strongly influences the outcome of receptor activation. AR coactivators serve as critical amplifiers that affect gene expression and transcription complex assembly in a context-specific manner. Since coactivators can demonstrate differential functions dependent on promoter context and/or in the presence of selected AR agonists, it is hypothesized that coactivators assist in controlling the ligand and tissue-specific activities of the receptor. Several distinct classes of AR coactivators have been identified, and these have been extensively reviewed (Heinlein \& Chang 2002, Culig et al. 2004; also see Androgen Receptor Mutations Database, http://www.androgendb.mcgill.ca/). In general, coactivators act directly or recruit enzymes to modify chromatin through either covalent histone modification (e.g. acetylation and methylation) or remodeling of chromatin structure (e.g. SWI/SNF complexes). Such modifications foster a state of open chromatin, allowing recruitment of basal transcription machinery and RNA polymerase II (Sommer \& Fuqua 2001, Urnov \& Wolffe 2001, Heinlein \& Chang 2002, Narlikar et al. 2002). More specialized AR coactivators serve to modulate association of the AR NTD with the carboxy terminal domain (N/C interaction). The AR N/C interaction is mediated through an FxxLF motif in the receptor NTD, which interacts with and occupies a hydrophobic cleft in the C-terminal AF-2 domain upon ligand binding (Zhou et al. 1994, He et al. 2000). Successful interaction of these two motifs is important for robust transcriptional activity, and recently it has been shown that the N/C interaction is critical for AR-chromatin association in cells (Li et al. 2005). Some coactivators, including steroid receptor coactivator 1 (SRC-1) and translation initiation factor 2 (TIF2), have been shown to facilitate N/C interaction and thus stabilize the AR-ligand association, promote subsequent coactivator recruitment, and enhance overall receptor stability (Ikonen et al. 1997, Berrevoets et al. 1998). Alternatively, factors that negatively modulate N/C interaction (e.g. MAGE-11) can induce AR activity by facilitating coactivator recruitment to the AF-2 domain (Bai et al. 2005). Thus, modulation of $\mathrm{N} / \mathrm{C}$ interactions represents a major mechanism by which coactivators govern AR activity.

Given the potent role of coactivators in enhancing AR function, it was suspected that AR effectors may be deregulated in a subset of prostate cancers. Emerging evidence supports this concept. For example, aberrant expression of the coactivators SRC-1 and TIF2 is associated with relapse after therapeutic intervention (Fujimoto et al. 2001, Gregory et al. 2001, Agoulnik et al. 2005). Additionally, the androgen receptorassociated proteins 70 (ARA70) and 55 (ARA55) can enhance AR activity in the presence of selected therapeutic AR antagonists (e.g. hydroxyflutamide; Miyamoto et al. 1998, Fujimoto et al. 1999). ARA70 expression is also induced post-castration in a xenograft prostate cancer model system, suggesting 
that this is one mechanism that facilitates the transition to therapeutic resistance (Gregory et al. 1998). Most recently, ARA70 expression was shown to be enhanced in the neoplastic prostate as compared with benign tissue, thus further implicating a role for this coactivator in prostate cancer progression (Hu et al. 2004). When combined, these observations indicate that cofactor deregulation may have significant impact on prostate cancer growth and progression. Here, we review the mechanisms of AR corepressor function and discuss the role of these cofactors in prostate cancer (Table 1).

\section{AR corepressors: mechanisms of action}

The mechanisms of corepressor action are as vast as that of their counterparts, the coactivators. By the classical definition, corepressors are those molecules that bind directly to AR and recruit chromatinmodifying enzymes that preclude transcriptional activation. However, a large number of molecules have been identified that negatively regulate $\mathrm{AR}$ activity through alternate mechanisms. For the purposes of this review, corepressors have been subdivided based on their mechanism of repression, including: (i) chromatin modification, (ii) regulation of AR N/C interaction, (iii) abrogation of AR-chromatin association or nuclear translocation, and/or (iv) inhibition of coactivator recruitment (Fig. 1).

Chromatin modifiers: Corepressors that trigger chromatin condensation and/or chromatin modifications typically recruit histone deacetylases (HDACs) to the AR complex. As mentioned, a certain subset of coactivators acetylate lysine residues on histone tails, thus loosening the association of nucleosomes with DNA and facilitating gene transcription (Fu et al. 2002a). HDACs counterbalance these affects through deacetylation of the same lysine residues, and this event results in both chromatin condensation and promoter inaccessibility (Sengupta \& Seto 2004). However, HDACs lack inherent DNAbinding capability, and also require activation by secondary molecules to induce enzymatic activity (Sengupta \& Seto 2004). For example, HDAC3 requires activation by nuclear receptor corepressor (NCoR) or silencing mediator of retinoic acid and thyroid hormone receptor (SMRT) to exert HDAC function (Alland et al. 1997, Heinzel et al. 1997, Wen et al. 2000). It is believed that these regulators exist in large repressor complexes that require additional alternate subunits, such as transducin $\beta$-like 1 (TBL1), for function (Yoon et al. 2003). Lastly, evidence suggests that HDACs may impinge on alternate, non-histone substrates to govern AR function. For example, AR itself is known to be acetylated by $\mathrm{p} 300 / \mathrm{CBP}-a s s o c i a t e d$ factor (P/CAF) in key lysine residues within the hinge region, and this modification has been shown to enhance AR activity and subsequent coactivator recruitment ( $\mathrm{Fu}$ et al. 2002b, 2003). It is presumed that a lysine deacetylase (such as HDAC) counterbalances this function. Thus, while it is clear that HDACs act in concert with NCoR and SMRT to elicit chromatin condensation, this class of repressor may directly modify the AR itself or other AR cofactors to modulate receptor activity.

Given the potent ability of HDACs to control chromatin structure, it is not surprising that many AR corepressors recruit HDACs (in addition to NCoR and SMRT) to induce transcriptional repression. Several AR corepressors are known to depend on HDAC function. Cyclin D1, protein inhibitor of activated STAT, PIAS $\gamma$, short heterodimer partner (SHP), and AR corepressor $-19 \mathrm{kDa}$ (ARR19) have been shown to directly interact with HDACs, and pharmacological inhibitors of HDAC function reduce the efficacy of each AR corepressor (Gobinet et al. 2001, Petre et al. 2002, Gross et al. 2004, Jeong et al. 2004). For example, cyclin D1 associates directly with HDAC3, and utilizes this mechanism to repress both AR and thyroid hormone receptor activity (Lin et al. 2002, Petre-Draviam et al. 2004). In both cases, cyclin D1 corepressor function was partially relieved upon treatment with trichostatin A (TSA), an established HDAC inhibitor (Lin et al. 2002, Petre et al. 2002). In addition, PIAS $\gamma$ has been shown to interact with HDAC1, and in this case, AR activity was completely restored in the presence of TSA (Gross et al. 2004). Thus, HDAC recruitment is a critical component of this class of corepressor.

Other AR corepressors (such as ErbB3-binding protein (EBP1), DJ1-binding protein (DJBP), and TG-interacting factor (TGIF); (Sharma \& Sun 2001, Niki et al. 2003, Zhang et al. 2005a)) employ Sin3 complexes to exert transcriptional repression, which consist of Sin3a and $\operatorname{Sin} 3 b$ in conjunction with either HDAC1 or HDAC2. The Sin3 complex is preassembled prior to chromatin recruitment; therefore, corepressors serve to provide specificity of Sin3 activity by recruiting the complex to appropriate gene targets (Silverstein \& Ekwall 2005). More specifically, EBP1 has been shown to be recruited to AR targets in the presence of therapeutic antagonists in concert with HDAC2 (Zhang et al. 2005b), thus providing evidence of EBP1 function in prostatic cancer therapy. Interestingly, the recently identified 


\begin{tabular}{|c|c|c|c|}
\hline Corepressor & Interaction & Mechanism & Biological relevance \\
\hline AES & NTD & ND & Prostatic epithelia expression \\
\hline ARA67/PAT1 & NTD/DBD/LBD & Cytoplasmic sequestration & PCa cell line expression \\
\hline $\begin{array}{l}\text { ARR19/Cmtm2a/ } \\
\text { Cklfsf2a }\end{array}$ & $\mathrm{DBD}$ & Recruits HDAC4 & $\begin{array}{l}\text { Expression in mouse prostate (weak), } \\
\text { not in human prostate }\end{array}$ \\
\hline Calreticulin & DBD & Inhibits DNA binding & ND \\
\hline Cyclin D1 & AR1-36, 626-666 & $\begin{array}{l}\text { Inhibits N/C, Recruits } \\
\text { HDACs sequestors } \\
\text { coactivators }\end{array}$ & $\begin{array}{l}\text { Altered localization or expression in } \\
\text { advanced disease, isoform } \\
\text { upregulated in PCa }\end{array}$ \\
\hline Dax-1/NROB1 & LBD & Inhibits N/C & $\begin{array}{l}\text { Expressed in prostatic epithelia, } \\
\text { absent in BPH }\end{array}$ \\
\hline DAXX/DAP6 & DBD & ND & ND \\
\hline DJBP & DBD & $\begin{array}{l}\text { Recruits Sin3a/ } \\
\text { HDACs }\end{array}$ & Expressed in testes \\
\hline EBP1 & NTD & Recruits Sin3a/HDAC2 & Prostatic epithelia expression \\
\hline FLNA & Hinge & $\begin{array}{l}\text { Inhibits N/C, suppresses } \\
\text { TIF2 activiation }\end{array}$ & PCa cell line expression \\
\hline Fox H1 & NTD & ND & ND \\
\hline GSK3 $\beta$ & NTD/LBD & $\begin{array}{l}\text { Inhibits } N / C \text {, Degrades } \\
\beta \text {-catenin }\end{array}$ & Overexpressed in PCa cell lines \\
\hline HBO1 & DBD-LBD & ND & Prostatic expression \\
\hline $\begin{array}{l}\text { Hey } 1 / \text { Hesr1/HRT1/ } \\
\text { CHF2/HERP2 }\end{array}$ & NTD & Possible HDAC recruitment & Cytoplasmic in PCa \\
\hline HOXB13 & ND & ND & Prostatic epethelia expression \\
\hline hRAD9 & LBD & Inhibits $\mathrm{N} / \mathrm{C}$ & Prostatic expression \\
\hline LATS2/KPM & LBD & Inhibits N/C & Decreased expression in $\mathrm{PCa}$ \\
\hline $\mathrm{N}-\mathrm{COR}$ & DBD & Recruits HDACs & $\begin{array}{l}\text { Critical for antagonist action, } \\
\text { deregulated in PCa by inflammation, } \\
\text { expressed in the prostate }\end{array}$ \\
\hline NF-KB & LBD & ND & Increased nuclear localization in $\mathrm{PCa}$ \\
\hline p53 & ND & Inhibits N/C, DNA binding & Mutated/lost in PCa \\
\hline PAK6 & LBD, AR634-668 & Cytoplasmic sequestration & Prostatic expression \\
\hline PIAS $^{\mathrm{a}}$ & AR1-333 & ND & Prostatic expression \\
\hline PIASy & DBD & Recruits HDACs & Prostatic expression \\
\hline PTEN & $\mathrm{DBD} / \mathrm{LBD}$ & $\begin{array}{l}\text { Cytoplasmic sequestration, } \\
\text { AR degradation }\end{array}$ & Mutated/lost in $\mathrm{PCa}$ \\
\hline PYK2/PTK2/FAK2 & Does not interact & $\begin{array}{l}\text { Phosphorylates ARA55 } \\
\text { and inactivates AR } \\
\text { coactivation }\end{array}$ & PCa cell lines \\
\hline
\end{tabular}

\section{Citations}

Yu et al. (2001)

Zhang et al. (2004)

Jeong et al. (2004) and Shi et al. (2005)

Dedhar et al. (1994)

Knudsen et al. (1999), Drobnjak (2000), Reutens et al. (2001), Petre et al. (2002), Petre-Draviam et al. (2003), Maddison et al. (2004), Burd et al. $(2005,2006)$

Yuan et al. (2001), Holter et al. (2002) and Agoulnik et al. (2003)

Lin et al. (2004a)

Niki et al. (2003)

Xia et al. (2001), Zhang et al. (2002, 2004, 2005a,b)

Loy et al. (2003)

Chen et al. (2005)

Wang et al. $(2004 a, b)$

Sharma et al. (2000)

Belandia et al. (2005)

Jung et al. (2004)

Wang et al. $(2004 a, b)$

Powzaniuk et al. (2004)

Cheng et al. (2002), Shang et al. (2002), Berrevoets et al. (2004),

Kang et al. (2004), Song et al. (2004), Hodgson et al. (2005), Yoon \& Wong (2005) and Zhu et al. (2006)

Palvimo et al. (1996), Cinar et al. (2004), Sweeney et al. (2004), Lessard et al. (2005)

Gumerlock et al. (1997), Shenk et al. (2001), Shi et al. (2002) Cronauer et al. (2004), Shi et al. (2004), Tsui et al. (2004)

Yang et al. (2001), Lee et al. (2002), Schrantz et al. (2004)

Junicho et al. (2000), Gross et al. (2001)

Gross et al. (2001, 2004)

McMenamin et al. (1999), Li et al. (2001), Halvorsen et al. (2003), Dreher et al. (2004), Lin et al. (2004b)

Wang et al. (2002) 


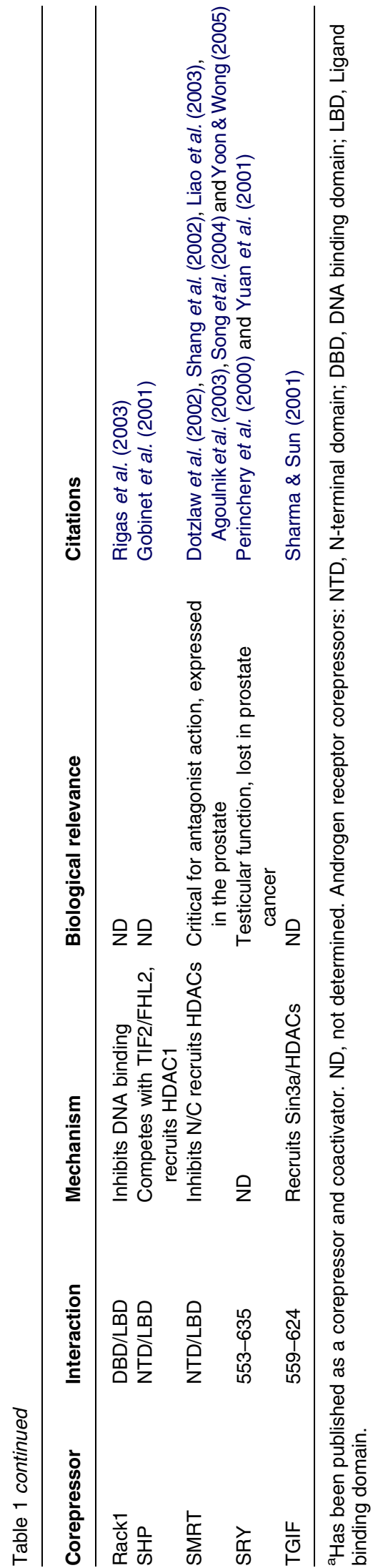

Hey1 corepressor links the Notch pathway to AR regulation and requires two distinct repressor domains to govern AR function (Belandia et al. 2005). While both the C-terminal and bHLH domains of Hey 1 utilize HDAC function, the latter can also act in a HDACindependent manner. As both domains are required to elicit transcriptional repression (Belandia et al. 2005), these data indicate that HDACs are not universally sufficient to suppress AR function. In sum, these observations reveal that chromatin-modifying enzymes, such as HDACs, play significant roles in eliciting AR corepressor function, and those corepressor molecules lend specificity to AR regulation.

Modulation of $A R N / C$ interactions: Upon ligand binding, the AR undergoes structural changes, thus providing a second mechanism by which corepressor molecules can dictate receptor function. As discussed previously, ligand binding stimulates an association between the ${ }^{23} \mathrm{FxxLF}^{27}$ motif and the hydrophobic surface of the AR LBD that results in enhanced receptor stability and activity (He et al. 2000). Moreover, N/C interactions can also modulate coactivator function (He et al. 2001, 2002). Recent evidence demonstrates that N/C interaction is essential for AR to effectively bind chromatin (but not naked DNA), thus underscoring the importance of this structural change (Li et al. 2005). The biological significance of $\mathrm{N} / \mathrm{C}$ association is well established, as genetic disruption results in weakened or lost receptor activity and the development of androgen insensitivity syndrome (Langley et al. 1998). Thus, N/C interaction represents a major mode of AR regulation that controls chromatin binding, receptor stability, and coactivator function.

Corepressors have been shown to modulate the N/C interaction through multiple mechanisms. First, selected corepressors prevent formation of the N/C interaction through intrinsic motifs that compete for binding. For example, hRad9 was identified as an AR corepressor through a yeast two-hybrid screen designed to identify factors that bind the AR DBD or LBD (Wang et al. 2004b). In these studies, an FxxLF motif within hRad9 was shown to compete for binding to the AR LBD, thus inhibiting N/C interaction and blocking AR activity (Wang et al. 2004b). A second class of N/C modifiers bind directly to regions of AR that mediate $\mathrm{N} / \mathrm{C}$ interaction, and are presumed to preclude efficient N/C interaction through steric hindrance. Such a mechanism is proposed for large tumor suppressor 2 (lats2), which associates with a residue in the AR LBD known to be required for N/C interaction (I898; Powzaniuk et al. 2004). By contrast, cyclin D1 inhibits N/C interaction by binding directly 


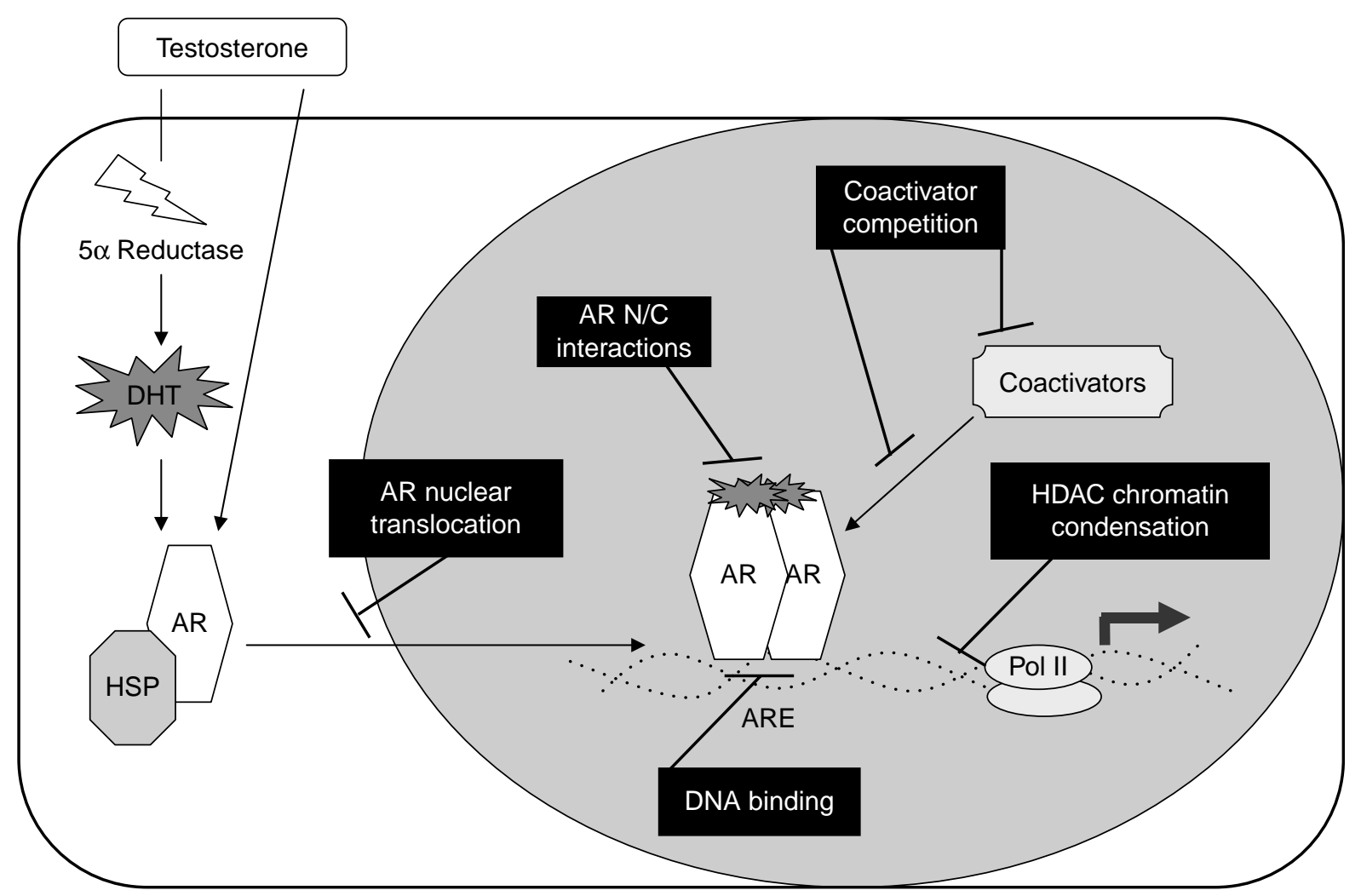

Figure 1 Diverse mechanisms of AR corepressor action. In prostate cancer cells, ligand (androgen) binding induces AR activity through stimulation of conformational changes in the receptor and nuclear translocation, wherein AR binds DNA through androgen-responsive elements. Subsequent coactivator recruitment facilitates gene activation. AR corepressors modulate AR activity through at least four divergent mechanisms, which serve to inhibit: (i) AR nuclear transactivation, (ii) N/C interaction, (iii) DNA binding, and/or (iv) coactivator recruitment. DHT, dihydrotestosterone; AR, androgen receptor; HSP, heat-shock protein; ARE, androgen-responsive element; HDAC, histone deacetylase; PollI, RNA polymerase II.

to the AR FxxLF region. The ability of cyclin D1 to bind the FxxLF motif is critical for its repressor function, and acts in concert with HDAC recruitment to impinge on AR activity (Burd et al. 2005). Lastly, several corepressors have been shown to block N/C interaction through as of yet undefined mechanisms. SMRT falls into this class, since the contact sites wherein SMRT interacts with AR (located in both the NTD and the LBD) are not known to be required for N/C interaction (Dotzlaw et al. 2002, Agoulnik et al. 2003, Liao et al. 2003). This is also true for filamin-A (FLNA), which binds the AR hinge region yet inhibits $\mathrm{N} / \mathrm{C}$ interaction (Loy et al. 2003), and for p53, which strongly inhibits N/C interaction through an undefined motif (Shenk et al. 2001). Recent evidence suggests that post-translational modifications can also influence the AR N/C interaction, as glycogen synthase kinase $3 \beta$ (GSK3 $\beta$; capable of binding both the AR NTD and the LBD) inhibits this interaction through a mechanism dependent on its kinase activity (Wang et al. 2004a).
These collective observations indicate that control of the N/C interaction is a major effector point for AR corepressors. Assessing the relative impact of these functions on receptor stability and chromatin association will help to establish the importance of N/C regulation for corepressor activity.

DNA binding/nuclear translocation: As a nuclear receptor, the ability of AR to translocate to the nucleus and bind target gene promoters is essential to its biological function (Jenster et al. 1993). A small group of corepressors impinge on these processes to modulate AR activity. An example is the phosphatase and tensin homolog deleted on chromosome 10 (PTEN) tumor suppressor, a phosphatase widely known for its role in preventing unscheduled cell cycle progression and cellular proliferation (Altomare \& Testa 2005). PTEN has been shown to sequester AR in the cytoplasm of LNCaP cells (Lin et al. 2004b), although the mechanisms by which PTEN exerts this effect are not understood. It has also been shown that PTEN leads to 
decreased AR stability and it is hypothesized that this destabilization event is functionally linked to cytoplasmic sequestration of AR (Lin et al. 2004b). Inhibition of AR nuclear translocation has also been observed with PAK6 (p21-activated kinase 6) and ARA67 (Schrantz et al. 2004, Zhang et al. 2004). Other corepressors have been shown to block the AR-DNA association using in vitro assays, including DAXX and calreticulin (Dedhar et al. 1994, Lin et al. 2004a); not surprisingly, each of these corepressors interact with the AR DBD. For calreticulin, this interaction is mediated through its KxGFFKR motif, which is homologous to a common motif found in nuclear receptor DBDs (Dedhar et al. 1994). As such, it is proposed that calreticulin may act as a general repressor of nuclear receptor action. In addition, Rack1 has been associated with decreased AR promoter occupancy through its activation of the protein kinase C (PKC) pathway (Rigas et al. 2003). Together, these corepressors limit AR function by inhibiting AR nuclear translocation and/ or DNA binding.

Coactivator competition: A number of AR corepressors function by inhibiting coactivator recruitment to the $\mathrm{AR}$ complex, as achieved through association with either AR or the coactivator itself. Both NCoR and SMRT have recently been shown to directly compete for coactivator recruitment by binding to AR. Ablation of either corepressor led to increased recruitment of the coactivators SRC-1 and p300 on endogenous AR targets (Kang et al. 2004, Hodgson et al. 2005, Yoon \& Wong 2005). Several other proteins, including SHP and filamin-A (FLNA) have also been shown to inhibit AR function by competing with coactivators (Gobinet et al. 2001, Loy et al. 2003). However, most studies rely on transient assays and ectopically expressed AR targets to establish the impact of corepressors on coactivator function. In these model systems, competition is implied by a corepressor's ability to overcome expression of a coactivator, but the mechanisms of action are not revealed by this methodology. For example, it is possible that this function of FLNA may be related to its ability to inhibit N/C interactions, as TIF2 is one of the coactivators thought to stabilize this AR conformation (Alen et al. 1999).

An alternate group of corepressors acts directly on coactivators to influence AR activity. In some cases, the besieged coactivator is targeted for degradation. Such is the case with GSK-3 $\beta$, which initiates degradation of $\beta$-catenin, an established AR coactivator
(Truica et al. 2000, Masiello et al. 2004). By contrast, the proline-rich tyrosine kinase 2 (PYK2) corepressor phosphorylates the coactivator ARA55, thus preventing its association with AR. PYK2 is unique among the identified corepressors as it does not interact with AR (Wang et al. 2002). Cyclin D1 has also been shown to bind to coactivators (SRC-1 and P/CAF; Zwijsen et al. 1998, McMahon et al. 1999), and a mechanism has been proposed wherein under specific conditions cyclin D1 can suppress coactivator function (Reutens et al. 2001). The forkhead box H1 (FOXH1) corepressor has been shown to bind numerous AR coactivators; however, the biological relevance of this activity for FOXH1 repressor function has yet to be determined (Chen et al. 2005).

Alternate mechanisms: Lastly, a group of corepressors has been identified for which the mechanisms of action remain elusive. One such corepressor is histone acetyltransferase binding to ORC1 (HBO1), a member of the MYST family that inhibits AR activity through binding the DBD-LBD (Sharma et al. 2000). The identification of HBO1 as a repressor was surprising, as this protein contains histone acetyltransferase activity inherent in many coactivators. However, published reports have not challenged the requirement of HBO1 enzymatic activity for its role as a corepressor. A second corepressor whose functions remain elusive is amino-terminus enhancer of split (AES), which represses AR through HDAC-independent means ( $\mathrm{Yu}$ et al. 2001). AES is known to interact with the basal transcription factor, TFIIE, but the relevance of this interaction for AR regulation is unknown. Finally, the PIAS family of proteins may modify AR function through post-translational modifications. The PIAS proteins are implicated in sumoylation of AR and harbor E3 sumoylation activity (Schmidt \& Muller 2003). Interestingly, while several PIAS proteins are AR coactivators, selected PIAS family members (e.g. PIAS3) have been shown to exert both coactivator and corepressor activities, dependent upon experimental conditions (Junicho et al. 2000, Kotaja et al. 2000, Gross et al. 2001). The requirement of enzymatic function for corepressor activity has yet to be established, although the SUMO E3 ligase activity has been implicated (Nishida \& Yasuda 2002).

In sum, corepressors impinge on virtually every facet of AR regulation, including modulation of AR localization, chromatin accessibility and binding, and cofactor recruitment. Given the importance of AR in prostate cancer, recent studies have begun to challenge the role of AR corepressors in this tumor type. 


\section{Corepressors and prostate cancer}

Despite the significant advances in identifying AR corepressors and their mechanisms of action, fewer studies have addressed their relevance for human disease. Emerging evidence indicates that alterations in AR corepressor regulation may significantly influence prostate cancer development and progression. As summarized later, present analyses have revealed specific roles for AR corepressors with variant functions in prostate cancer (Fig. 2).

NCoR and SMRT: As described previously, NCoR and SMRT are master regulators of HDAC activity, and repress AR function through their ability to activate these chromatin-modifying enzymes (Cheng et al. 2002, Shang et al. 2002). In the context of prostate cancer, this function of NCoR and SMRT is particularly salient for the treatment of metastatic disease. First-line therapy for disseminated prostate cancer consists of androgendeprivation therapy used prior to or in combination with AR antagonists, such as bicalutamide (Denmeade \& Isaacs 2002, Salesi et al. 2005). It was previously thought that $\mathrm{AR}$ antagonists function passively by competing with androgen for binding to the LBD, and thereby precluding formation of an active receptor complex. However, groundbreaking studies demonstrated that antagonists, such as bicalutamide, also initiate recruitment of corepressors to the AR complex, thus actively repressing transcription from AR target genes (Shang et al. 2002, Song et al. 2004, Yoon \& Wong 2005). Analysis of antagonist-induced AR complexes indicated that NCoR and SMRT (in addition to HDACs) are critical components of this process (Shang et al. 2002). Other therapeutic agents, such as the partial antagonists mifepristone and cyproterone acetate specifically induce NCoR recruitment (Hodgson et al. 2005). Elimination of NCoR or SMRT reduced the efficacy of AR antagonists when transcription from endogenous target genes was monitored (Yoon \& Wong 2005). Thus, NCoR and SMRT are critical effectors of AR antagonist function.

Most recently, it was shown that inflammation and consequent macrophage infiltration into prostate tumors initiates a signaling cascade that disrupts NCoR and HDAC activity (Zhu et al. 2006). Specifically, in the presence of selective androgen receptor antagonists, macrophages were demonstrated to signal through IL-1 $\beta$ and MEKK1 to activate TAB2, a 'molecular beacon' that is responsive to inflammatory signaling pathways. TAB2 subsequently dismisses the NCoR holocorepressor complex (including TBL1/TBLR1-, Sin3a, and $\mathrm{Brg} 1$ ), from $\mathrm{AR}$, thus resulting in derepression of AR activity. The ability of TAB2 to exert this activity

\section{Corepressor action in prostate cancer}

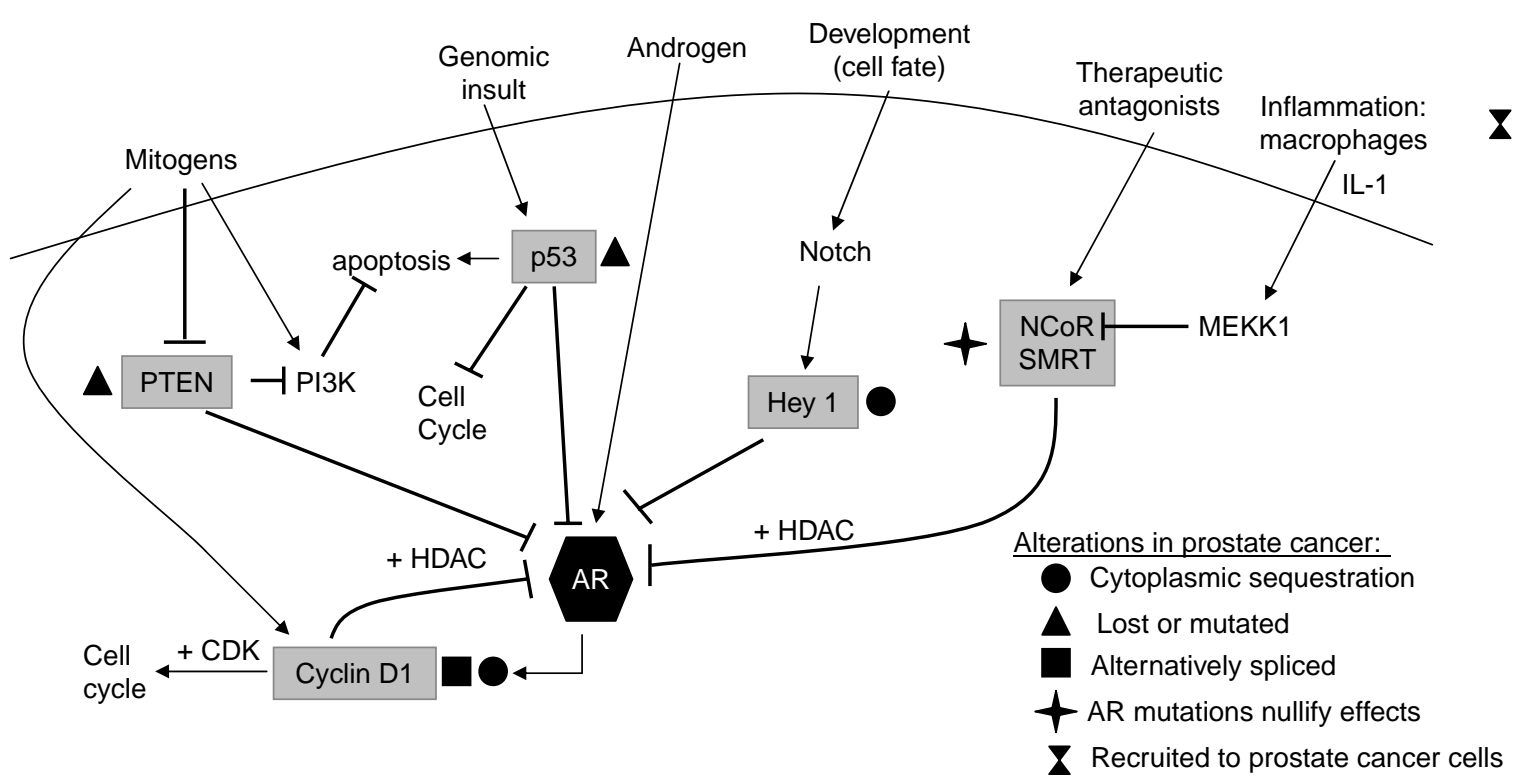

Figure 2 Actions of corepressors in PCa. Numerous AR corepressors (highlighted in gray boxes) are altered in prostate cancer through various diverse pathways. Alterations of corepressor function in prostate cancer include loss of function (cytoplasmic sequestration, loss, mutation, and alternative splicing), a bypass of corepressor sensitivity (through AR mutation), and displacement of corepressors (achieved via signal transduction). 
is dependent on an N-terminal, evolutionarily conserved AR motif that is a critical effector of $A R$ function, thus underscoring the importance of this motif (Callewaert et al. 2006, Zhu et al. 2006). The clinical relevance of these findings is potentially high, as IL-1 $\beta$ effectively converted therapeutic AR antagonists to agonists (Zhu et al. 2006). Together, these observations support the hypothesis that alterations in expression and/or recruitment of NCoR and SMRT may facilitate tumor recurrence after therapeutic intervention. This hypothesis has yet to be confirmed in human tumors, as few published studies have examined corepressor expression during disease progression. One study examining the impact of the vitamin D3 receptor in prostate cancer did demonstrate an increase in SMRT mRNA levels (with no changes in NCoR); however, these studies considered only naïve tumors (Khanim et al. 2004). In sum, while there is a clear role for $\mathrm{NCoR}$ and SMRT in the molecular response to AR antagonists, the contribution of these corepressors for disease progression and therapeutic efficacy awaits further investigation.

PTEN: The PTEN tumor suppressor is a critical regulator of prostate cancer growth and progression, and has established utility as a prognostic factor in this disease. PTEN is frequently lost in prostate cancer (approximately 20-27\% frequency) and its loss is associated with decreased survival rates (McMenamin et al. 1999, Halvorsen et al. 2003). Moreover, mice heterozygous for PTEN develop prostatic intraepithelia neoplasia (PIN), and combined genetic deletion of factors that control cell cycle progression (such as the CDK inhibitor p27kip1 or the retinoblastoma tumorsuppressor protein, RB) result in carcinoma (Di Cristofano et al. 2001, Hill et al. 2005). Prostatespecific deletion of PTEN alone induces metastatic prostate cancer (Wang et al. 2003), and PTEN heterozygosity promotes tumor progression in the TRAMP prostate cancer model (Kwabi-Addo et al. 2001). Interestingly, PTEN disruption also signals to inhibit GSK3 $\beta$ activity, thereby indicating that PTEN can also regulate the function of other AR corepressors. While it is tempting to speculate that the role of PTEN as a tumor suppressor in this tissue type is attributed to its ability to serve as an AR corepressor, this assumption is confounded by the established role of PTEN in controlling factors that regulate cell survival (e.g. AKT) or cell cycle progression (e.g. p27; Gottschalk et al. 2001, Paez \& Sellers 2003). It is suspected that PTEN and androgen act in opposition, as the ability of PTEN to induce apoptosis in prostate cancer cells is reversed by androgen. These observations led to speculation that PTEN loss may result in enhanced AR activity and also promote resistance to therapy-induced cell death ( $\mathrm{Li}$ et al. 2001). Indeed, loss of PTEN is independently predictive of a shortened time to biochemical failure (i.e. rises in PSA after therapeutic intervention) and tumor recurrence (Halvorsen et al. 2003). Future studies directed at delineating PTEN action in this tumor type will assist in determining the relevance of its role as an AR corepressor.

Cyclin D1: The role of cyclin D1 in prostate cancer is pleiotropic, as this molecule controls both AR function and cell cycle regulation (Knudsen et al. 1998, 1999, Coqueret 2002, Petre et al. 2002). It is well documented that in prostate cancer cells, androgen induces cyclin D1 accumulation, and this induction in cyclin D1 is required to stimulate cyclin-dependent kinase 4 (CDK4) activity and concomitant cell cycle progression (Lu et al. 1997, Knudsen et al. 1998). However, it is known that AR activity is regulated as a function of the cell cycle, wherein AR activity is lowest at the G1-S transition, when cyclin D1 levels peak (Martinez \& Danielsen 2002). The ability of cyclin D1 to directly bind and inhibit AR is thought to underlie this regulation, and is proposed to serve as a negative feedback switch to modulate the mitogenic activity of androgen (Petre et al. 2002). Supporting this hypothesis, cyclin D1 induction in prostate cancer cells has been shown to inhibit cellular proliferation through its ability to regulate AR (Petre et al. 2002, Burd et al. 2006). Recent studies indicate that this function of cyclin D1 may be altered in prostate cancer. First, murine models of prostate cancer demonstrate that cyclin D1 expression decreases as a function of disease progression (Maddison et al. 2004). It has also been reported that cyclin D1 may be sequestered in the cytoplasm (and potentially precluded from CDK4 or AR regulation) in human tumors (Maddison et al. 2004). A mechanism underlying this event could in fact be GSK3 $\beta$, which is known to phosphorylate cyclin D1 and thereby mark the protein for rapid nuclear export (Diehl et al. 1998). Interestingly, GSK3 $\beta$ is reported to have increased expression in prostatic cancer cell lines (Wang et al. 2004a). Second, it was recently shown that a variant of cyclin D1 that arises from alternate splicing (cyclin D1b) is expressed at high levels in a subset of prostate cancers and pre-cancerous (PIN) lesions (Burd et al. 2006). This variant of cyclin D1 was shown to be altered in its ability to regulate $A R$ function, and was unable to attenuate 
cellular proliferation in prostate cancer cells (Burd et al. 2006). Thus, cyclin D1 corepressor function and expression of cyclin D1 variants may hold significance for the response to androgen stimulation and AR regulation in prostate cancer.

p53: The importance of p53 mutation and loss on cancer development and progression is well established, and in prostate cancer mutations of p53 have been identified in $45 \%$ of radical prostatectomy samples (Shi et al. 2004). However, as with PTEN, the AR repressor function is confounded by its role as tumor-suppressor protein. A recent study investigating 16 mutant alleles of p53 identified in prostate cancer showed loss of p53 transactivation potential (Shi et al. 2002). The ability of these mutants to regulate AR function was not assessed, but the majority of these mutations had been previously identified in other tumor types, suggesting that they result in loss of classical p53 function. Clearly, further experimental consideration is needed to dissect the multiple functions of p53 in prostate cancer.

Hey1: Lastly, the Hey1 corepressor is regulated by the Notch pathway, which controls cell fate (Iso et al. 2001). Both Notch and Heyl are expressed in normal prostatic epithelia, and Notch activation is known to inhibit cellular proliferation in cells of the prostate (Shou et al. 2001, Belandia et al. 2005). Conversely, Notch and its ligand (jagged) are downregulated by androgen stimulation, whereas negative regulators of the Notch pathway are induced. These observations indicate that Notch signaling negatively regulates androgen action through activation of Hey1. Although Hey 1 resides in a region of chromosome 8 known to be amplified in prostate cancer, further investigation revealed that Hey1 localization is altered in cancer. Specifically, Hey1 is sequestered in the cytoplasm of prostate cancer cells, whereas the protein colocalizes with AR in both the cytoplasm and nucleus of nonmalignant prostate epithelia (Belandia et al. 2005). Therefore, sequestration of Heyl in prostate cancer cells may represent one mechanism by which tumor cells evade the inhibitory and anti-mitogenic functions of Notch signaling.

\section{Conclusions}

The androgen receptor is a critical effector of prostate cancer development and progression. Inhibition of AR activity is the central goal of therapeutic intervention, and recurrent tumors arise with restored AR activity. Given the importance of
AR in this deadly disease, a concerted effort has been implemented to delineate the cofactors that govern AR action, and to identify aberrations in AR control that may facilitate therapeutic bypass. It is clear that AR coactivators can contribute to this process by enhancing AR activity under conditions of androgen deprivation. Identification of $A R$ corepressors significantly lagged behind advances in coactivator function, and prior to the millennium only a handful of AR corepressors had been described. In the last 5 years, there has been an expansion in corepressor discovery. Biochemical analysis of corepressor action revealed that this class of molecule can utilize widely disparate mechanisms to control AR function. These modes of action include those that are general to transcriptional control (e.g. recruitment of enzymes that modify chromatin) or unique to the receptor (e.g. inhibition of N/C interaction). Many AR corepressors have been previously defined as participating in pathways as disparate as signal transduction pathways (e.g. PTEN) or cell cycle control (e.g. cyclin D1), thus indicating that corepressors provide crosstalk mechanisms for pathways that also impinge on proliferation. The concept that AR corepressor function could be compromised in prostate cancer progression (and thus contribute to deregulated AR activity) is emerging, and analyses of effects on influential AR targets in prostate cancer (such as the TMPRSS2ERG translocation; Tomlins et al. 2005) should be considered. Future investigations into the clinical relevance of AR corepressors will provide additional insight into the mechanisms by which tumor cells escape therapy, and could reveal additional execution points for novel therapeutic intervention.

\section{Acknowledgements}

We thank Drs Steven Balk, Charlotte Bevan, Frank Claessens, Ed Gelmann, Erik Knudsen, Elizabeth Wilson, and Jiemin Wong for critical reading of this manuscript and invaluable suggestions. We would also like to thank all members of the K Knudsen lab for their insight and ongoing critical discussions, with special recognition to Janet Hess-Wilson for presentation assistance. The authors declare that there is no conflict of interest that would prejudice the impartiality of this scientific work. 


\section{References}

Agoulnik IU, Krause WC, Bingman WE, III, Rahman HT, Amrikachi M, Ayala GE \& Weigel NL 2003 Repressors of androgen and progesterone receptor action. Journal of Biological Chemistry 278 31136-31148.

Agoulnik IU, Vaid A, Bingman WE, III, Erdeme H, Frolov A, Smith CL, Ayala G, Ittmann MM \& Weigel NL 2005 Role of SRC-1 in the promotion of prostate cancer cell growth and tumor progression. Cancer Research 65 7959-7967.

Agus DB, Cordon-Cardo C, Fox W, Drobnjak M, Koff A, Golde DW \& Scher HI 1999 Prostate cancer cell cycle regulators: response to androgen withdrawal and development of androgen independence. Journal of the National Cancer Institute 91 1869-1876.

Alen P, Claessens F, Verhoeven G, Rombauts W \& Peeters B 1999 The androgen receptor amino-terminal domain plays a key role in p160 coactivatorstimulated gene transcription. Molecular and Cellular Biology 19 6085-6097.

Alland L, Muhle R, Hou H Jr, Potes J, Chin L, SchreiberAgus N \& DePinho RA 1997 Role for N-CoR and histone deacetylase in Sin3-mediated transcriptional repression. Nature 387 49-55.

Altomare DA \& Testa JR 2005 Perturbations of the AKT signaling pathway in human cancer. Oncogene 24 7455-7464.

Bai S, He B \& Wilson EM 2005 Melanoma antigen gene protein MAGE-11 regulates androgen receptor function by modulating the interdomain interaction. Molecular and Cellular Biology 25 1238-1257.

Belandia B, Powell SM, Garcia-Pedrero JM, Walker MM, Bevan CL \& Parker MG 2005 Hey1, a mediator of notch signaling, is an androgen receptor corepressor. Molecular and Cellular Biology 25 1425-1436.

Berrevoets CA, Doesburg P, Steketee K, Trapman J \& Brinkmann AO 1998 Functional interactions of the AF-2 activation domain core region of the human androgen receptor with the amino-terminal domain and with the transcriptional coactivator TIF2 (transcriptional intermediary factor2). Molecular Endocrinology 12 1172-1183.

Berrevoets CA, Umar A, Trapman J \& Brinkmann AO 2004 Differential modulation of androgen receptor transcriptional activity by the nuclear receptor co-repressor $(\mathrm{N}$ CoR). Biochemical Journal 379 731-738.

Brinkmann AO, Blok LJ, de Ruiter PE, Doesburg P, Steketee K, Berrevoets CA \& Trapman J 1999 Mechanisms of androgen receptor activation and function. Journal of Steroid Biochemistry and Molecular Biology 69 307-313.

Burd CJ, Petre CE, Moghadam H, Wilson EM \& Knudsen KE 2005 Cyclin D1 binding to the androgen receptor (AR) NH2-terminal domain inhibits activation function 2 association and reveals dual roles for AR corepression. Molecular Endocrinology 19 607-620.

Burd CJ, Petre CE, Morey LM, Wang Y, Revelo MP, Haiman CA, Lu S, Fenoglio-Preiser CM, Li J, Knudsen ES et al.
2006 Cyclin D1b variant influences prostate cancer growth through aberrant androgen receptor regulation. PNAS 103 2190-2195.

Callewaert L, Van Tilborgh N \& Claessens F 2006 Interplay between two hormone-independent activation domains in the androgen receptor. Cancer Research $66543-553$.

Chen G, Nomura M, Morinaga H, Matsubara E, Okabe T, Goto K, Yanase T, Zheng H, Lu J \& Nawata H 2005 Modulation of androgen receptor transactivation by FoxH1. A newly identified androgen receptor corepressor. Journal of Biological Chemistry 280 36355-36363.

Cheng S, Brzostek S, Lee SR, Hollenberg AN \& Balk SP 2002 Inhibition of the dihydrotestosterone-activated androgen receptor by nuclear receptor corepressor. Molecular Endocrinology 16 1492-1501.

Cinar B, Yeung F, Konaka H, Mayo MW, Freeman MR, Zhau HE \& Chung LW 2004 Identification of a negative regulatory cis-element in the enhancer core region of the prostate-specific antigen promoter: implications for intersection of androgen receptor and nuclear factorkappaB signalling in prostate cancer cells. Biochemical Journal 379 421-431.

Coqueret O 2002 Linking cyclins to transcriptional control. Gene 299 35-55.

Cronauer MV, Schulz WA, Burchardt T, Ackermann R \& Burchardt M 2004 Inhibition of p53 function diminishes androgen receptor-mediated signaling in prostate cancer cell lines. Oncogene 23 3541-3549.

Culig Z, Comuzzi B, Steiner H, Bartsch G \& Hobisch A 2004 Expression and function of androgen receptor coactivators in prostate cancer. Journal of Steroid Biochemistry and Molecular Biology 92 265-271.

Dedhar S, Rennie PS, Shago M, Hagesteijn CY, Yang H, Filmus J, Hawley RG, Bruchovsky N, Cheng H, Matusik RJ et al. 1994 Inhibition of nuclear hormone receptor activity by calreticulin. Nature 367 480-483.

Denmeade SR \& Isaacs JT 2002 A history of prostate cancer treatment. Nature Reviews Cancer 2 389-396.

Denmeade SR, Lin XS \& Isaacs JT 1996 Role of programmed (apoptotic) cell death during the progression and therapy for prostate cancer. Prostate 28 251-265.

Di Cristofano A, De Acetis M, Koff A, Cordon-Cardo C \& Pandolfi PP 2001 Pten and p27KIP1 cooperate in prostate cancer tumor suppression in the mouse. Nature Genetics 27 222-224.

Diehl JA, Cheng M, Roussel MF \& Sherr CJ 1998 Glycogen synthase kinase-3beta regulates cyclin D1 proteolysis and subcellular localization. Genes \& Development 12 3499-3511.

Dotzlaw H, Moehren U, Mink S, Cato AC, Iniguez Lluhi JA \& Baniahmad A 2002 The amino terminus of the human $\mathrm{AR}$ is target for corepressor action and antihormone agonism. Molecular Endocrinology 16 661-673.

Dreher T, Zentgraf H, Abel U, Kappeler A, Michel MS, Bleyl U \& Grobholz R 2004 Reduction of PTEN and 
p27kip1 expression correlates with tumor grade in prostate cancer. Analysis in radical prostatectomy specimens and needle biopsies. Virchows Archiv 444 509-517.

Evans RM 1988 The steroid and thyroid hormone receptor superfamily. Science 240 889-895.

Feldman BJ \& Feldman D 2001 The development of androgen-independent prostate cancer. Nature Reviews Cancer $134-45$.

Fu M, Wang C, Wang J, Zafonte BT, Lisanti MP \& Pestell RG $2002 a$ Acetylation in hormone signaling and the cell cycle. Cytokine \& Growth Factor Reviews 13 259-276.

Fu M, Wang C, Wang J, Zhang X, Sakamaki T, Yeung YG, Chang C, Hopp T, Fuqua SA, Jaffray E et al. 2002b Androgen receptor acetylation governs trans activation and MEKK1-induced apoptosis without affecting in vitro sumoylation and trans-repression function. Molecular and Cellular Biology 22 3373-3388.

Fu M, Rao M, Wang C, Sakamaki T, Wang J, Di Vizio D, Zhang X, Albanese C, Balk S, Chang C et al. 2003 Acetylation of androgen receptor enhances coactivator binding and promotes prostate cancer cell growth. Molecular and Cellular Biology 23 8563-8575.

Fujimoto N, Yeh S, Kang HY, Inui S, Chang HC, Mizokami A \& Chang C 1999 Cloning and characterization of androgen receptor coactivator, ARA55, in human prostate. Journal of Biological Chemistry 274 8316-8321.

Fujimoto N, Mizokami A, Harada S \& Matsumoto T 2001 Different expression of androgen receptor coactivators in human prostate. Urology 58 289-294.

Gelmann EP 2002 Molecular biology of the androgen receptor. Journal of Clinical Oncology 20 3001-3015.

Gobinet J, Auzou G, Nicolas JC, Sultan C \& Jalaguier S 2001 Characterization of the interaction between androgen receptor and a new transcriptional inhibitor, SHP. Biochemistry 40 15369-15377.

Gottschalk AR, Basila D, Wong M, Dean NM, Brandts CH, Stokoe D \& Haas-Kogan DA 2001 p27Kip1 is required for PTEN-induced G1 growth arrest. Cancer Research $\mathbf{6 1}$ 2105-2111.

Gregory CW, Hamil KG, Kim D, Hall SH, Pretlow TG, Mohler JL \& French FS 1998 Androgen receptor expression in androgen-independent prostate cancer is associated with increased expression of androgenregulated genes. Cancer Research 58 5718-5724.

Gregory CW, He B, Johnson RT, Ford OH, Mohler JL, French FS \& Wilson EM 2001 A mechanism for androgen receptor-mediated prostate cancer recurrence after androgen deprivation therapy. Cancer Research 61 4315-4319.

Gross M, Liu B, Tan J, French FS, Carey M \& Shuai K 2001 Distinct effects of PIAS proteins on androgen-mediated gene activation in prostate cancer cells. Oncogene 20 3880-3887.

Gross M, Yang R, Top I, Gasper C \& Shuai K 2004 PIASymediated repression of the androgen receptor is independent of sumoylation. Oncogene 23 3059-3066.
Gumerlock PH, Chi SG, Shi XB, Voeller HJ, Jacobson JW, Gelmann EP \& deVere White RW 1997 p53 abnormalities in primary prostate cancer: single-strand conformation polymorphism analysis of complementary DNA in comparison with genomic DNA. The Cooperative Prostate Network. Journal of the National Cancer Institute 89 66-71.

Halvorsen OJ, Haukaas SA \& Akslen LA 2003 Combined loss of PTEN and p27 expression is associated with tumor cell proliferation by Ki-67 and increased risk of recurrent disease in localized prostate cancer. Clinical Cancer Research 9 1474-1479.

He B, Kemppainen JA \& Wilson EM 2000 FXXLF and WXXLF sequences mediate the NH2-terminal interaction with the ligand binding domain of the androgen receptor. Journal of Biological Chemistry 275 22986-22994.

He B, Bowen NT, Minges JT \& Wilson EM 2001 Androgen-induced NH2- and $\mathrm{COOH}$-terminal Interaction Inhibits p160 coactivator recruitment by activation function 2. Journal of Biological Chemistry 276 42293-42301.

He B, Minges JT, Lee LW \& Wilson EM 2002 The FXXLF motif mediates androgen receptor-specific interactions with coregulators. Journal of Biological Chemistry 277 10226-10235.

He B, Gampe RT, Jr, Hnat AT, Faggart JL, Minges JT, French FS \& Wilson EM 2006 Probing the functional link between androgen receptor coactivator and ligand-binding sites in prostate cancer and androgen insensitivity. Journal of Biological Chemistry $\mathbf{2 8 1}$ 6648-6663.

Heinlein CA \& Chang C 2002 Androgen receptor (AR) coregulators: an overview. Endocrine Reviews 23 175-200.

Heinzel T, Lavinsky RM, Mullen TM, Soderstrom M, Laherty CD, Torchia J, Yang WM, Brard G, Ngo SD, Davie JR et al. 1997 A complex containing N-CoR, $\mathrm{mSin} 3$ and histone deacetylase mediates transcriptional repression. Nature 387 43-48.

Hill R, Song Y, Cardiff RD \& Van Dyke T 2005 Heterogeneous tumor evolution initiated by loss of $\mathrm{pRb}$ function in a preclinical prostate cancer model. Cancer Research 65 10243-10254.

Hodgson MC, Astapova I, Cheng S, Lee LJ, Verhoeven MC, Choi E, Balk SP \& Hollenberg AN 2005 The androgen receptor recruits nuclear receptor CoRepressor $(\mathrm{N}-\mathrm{CoR})$ in the presence of mifepristone via its $\mathrm{N}$ and $\mathrm{C}$ termini revealing a novel molecular mechanism for androgen receptor antagonists. Journal of Biological Chemistry 280 6511-6519.

Holter E, Kotaja N, Makela S, Strauss L, Kietz S, Janne OA, Gustafsson JA, Palvimo JJ \& Treuter E 2002 Inhibition of androgen receptor (AR) function by the reproductive orphan nuclear receptor DAX-1. Molecular Endocrinology 16 515-528.

Hu YC, Yeh S, Yeh SD, Sampson ER, Huang J, Li P, Hsu CL, Ting HJ, Lin HK, Wang L et al. 2004 
Functional domain and motif analyses of androgen receptor coregulator ARA70 and its differential expression in prostate cancer. Journal of Biological Chemistry 279 33438-33446.

Ikonen T, Palvimo JJ \& Janne OA 1997 Interaction between the amino- and carboxyl-terminal regions of the rat androgen receptor modulates transcriptional activity and is influenced by nuclear receptor coactivators. Journal of Biological Chemistry 272 29821-29828.

Iso T, Sartorelli V, Chung G, Shichinohe T, Kedes L \& Hamamori Y 2001 HERP, a new primary target of Notch regulated by ligand binding. Molecular and Cellular Biology 21 6071-6079.

Jemal A, Siegel R, Ward E, Murray T, Xu J, Smigal C \& Thun MJ 2006 Cancer statistics. CA: A Cancer Journal for Clinicians 56 106-130.

Jenster G 1998 Coactivators and corepressors as mediators of nuclear receptor function: an update. Molecular and Cellular Endocrinology 143 1-7.

Jenster G 1999 The role of the androgen receptor in the development and progression of prostate cancer. Seminars in Oncology 26 407-421.

Jenster G, van der Korput JA, Trapman J \& Brinkmann AO 1992 Functional domains of the human androgen receptor. Journal of Steroid Biochemistry and Molecular Biology 41 671-675.

Jenster G, Trapman J \& Brinkmann AO 1993 Nuclear import of the human androgen receptor. Biochemical Journal 293 761-768.

Jeong BC, Hong CY, Chattopadhyay S, Park JH, Gong EY, Kim HJ, Chun SY \& Lee K 2004 Androgen receptor corepressor-19 $\mathrm{kDa}$ (ARR19), a leucine-rich protein that represses the transcriptional activity of androgen receptor through recruitment of histone deacetylase. Molecular Endocrinology 18 13-25.

Jung C, Kim RS, Zhang HJ, Lee SJ \& Jeng MH 2004 HOXB13 induces growth suppression of prostate cancer cells as a repressor of hormone-activated androgen receptor signaling. Cancer Research 64 9185-9192.

Junicho A, Matsuda T, Yamamoto T, Kishi H, Korkmaz K, Saatcioglu F, Fuse H \& Muraguchi A 2000 Protein inhibitor of activated STAT3 regulates androgen receptor signaling in prostate carcinoma cells. Biochemical and Biophysical Research Communications 278 9-13.

Kang Z, Janne OA \& Palvimo JJ 2004 Coregulator recruitment and histone modifications in transcriptional regulation by the androgen receptor. Molecular Endocrinology 18 2633-2648.

Khanim FL, Gommersall LM, Wood VH, Smith KL, Montalvo L, O’Neill LP, Xu Y, Peehl DM, Stewart PM, Turner BM et al. 2004 Altered SMRT levels disrupt vitamin D3 receptor signalling in prostate cancer cells. Oncogene 23 6712-6725.
Knudsen KE, Arden KC \& Cavenee WK 1998 Multiple G1 regulatory elements control the androgen-dependent proliferation of prostatic carcinoma cells. Journal of Biological Chemistry 273 20213-20222.

Knudsen KE, Cavenee WK \& Arden KC 1999 D-type cyclins complex with the androgen receptor and inhibit its transcriptional transactivation ability. Cancer Research 59 2297-2301.

Kotaja N, Aittomaki S, Silvennoinen O, Palvimo JJ \& Janne OA 2000 ARIP3 (androgen receptor-interacting protein 3) and other PIAS (protein inhibitor of activated STAT) proteins differ in their ability to modulate steroid receptor-dependent transcriptional activation. Molecular Endocrinology 14 1986-2000.

Kwabi-Addo B, Giri D, Schmidt K, Podsypanina K, Parsons R, Greenberg N \& Ittmann M 2001 Haploinsufficiency of the Pten tumor suppressor gene promotes prostate cancer progression. PNAS 98 11563-11568.

Langley E, Kemppainen JA \& Wilson EM 1998 Intermolecular NH2-/carboxyl-terminal interactions in androgen receptor dimerization revealed by mutations that cause androgen insensitivity. Journal of Biological Chemistry 273 92-101.

Lee SR, Ramos SM, Ko A, Masiello D, Swanson KD, Lu ML \& Balk SP 2002 AR and ER interaction with a p21activated kinase (PAK6). Molecular Endocrinology 16 85-99.

Lessard L, Begin LR, Gleave ME, Mes-Masson AM \& Saad F 2005 Nuclear localisation of nuclear factorkappaB transcription factors in prostate cancer: an immunohistochemical study. British Journal of Cancer 93 1019-1023.

Li P, Nicosia SV \& Bai W 2001 Antagonism between PTEN/MMAC1/TEP-1 and androgen receptor in growth and apoptosis of prostatic cancer cells. Journal of Biological Chemistry 276 20444-20450.

Li J, Fu J, Toumazou C, Yoon HG \& Wong J 2005 A role of the amino-terminal $(\mathrm{N})$ and carboxyl-terminal $(\mathrm{C})$ interaction in binding of androgen receptor to chromatin. Molecular Endocrinology 20 776-785.

Liao G, Chen LY, Zhang A, Godavarthy A, Xia F, Ghosh JC, Li H \& Chen JD 2003 Regulation of androgen receptor activity by the nuclear receptor corepressor SMRT. Journal of Biological Chemistry 278 5052-5061.

Lin HM, Zhao L \& Cheng SY 2002 Is a ligand-independent co-repressor for thyroid hormone receptors. Journal of Biological Chemistry 277 28733-28741.

Lin DY, Fang HI, Ma AH, Huang YS, Pu YS, Jenster G, Kung HJ \& Shih HM 2004a Negative modulation of androgen receptor transcriptional activity by Daxx. Molecular and Cellular Biology 24 10529-10541.

Lin HK, Hu YC, Lee DK \& Chang C 2004b Regulation of androgen receptor signaling by PTEN (phosphatase and tensin homolog deleted on chromosome 10) tumor suppressor through distinct mechanisms in prostate cancer cells. Molecular Endocrinology 18 2409-2423. 
Loy CJ, Sim KS \& Yong EL 2003 Filamin-A fragment localizes to the nucleus to regulate androgen receptor and coactivator functions. PNAS 100 4562-4567.

Lu S, Tsai SY \& Tsai MJ 1997 Regulation of androgendependent prostatic cancer cell growth: androgen regulation of CDK2, CDK4, and CKI p16 genes. Cancer Research 57 4511-4516.

Maddison LA, Huss WJ, Barrios RM \& Greenberg NM 2004 Differential expression of cell cycle regulatory molecules and evidence for a 'cyclin switch' during progression of prostate cancer. Prostate 58 335-344.

Mangelsdorf DJ, Thummel C, Beato M, Herrlich P, Schutz G, Umesono K, Blumberg B, Kastner P, Mark M, Chambon $\mathrm{P}$ et al. 1995 The nuclear receptor superfamily: the second decade. Cell 83 835-839.

Marivoet S, Van Dijck P, Verhoeven G \& Heyns W 1992 Interaction of the $90-\mathrm{kDa}$ heat shock protein with native and in vitro translated androgen receptor and receptor fragments. Molecular and Cellular Endocrinology $\mathbf{8 8}$ 165-174.

Martinez ED \& Danielsen M 2002 Loss of androgen receptor transcriptional activity at the G(1)/S transition. Journal of Biological Chemistry 277 29719-29729.

Masiello D, Chen SY, Xu Y, Verhoeven MC, Choi E, Hollenberg AN \& Balk SP 2004 Recruitment of beta-catenin by wild-type or mutant androgen receptors correlates with ligand-stimulated growth of prostate cancer cells. Molecular Endocrinology 18 2388-2401.

McMahon C, Suthiphongchai T, DiRenzo J \& Ewen ME 1999 P/CAF associates with cyclin D1 and potentiates its activation of the estrogen receptor. PNAS 96 5382-5387.

McMenamin ME, Soung P, Perera S, Kaplan I, Loda M \& Sellers WR 1999 Loss of PTEN expression in paraffinembedded primary prostate cancer correlates with high Gleason score and advanced stage. Cancer Research 59 4291-4296.

Miyamoto H, Yeh S, Wilding G \& Chang C 1998 Promotion of agonist activity of antiandrogens by the androgen receptor coactivator, ARA70, in human prostate cancer DU145 cells. PNAS 95 7379-7384.

Narlikar GJ, Fan HY \& Kingston RE 2002 Cooperation between complexes that regulate chromatin structure and transcription. Cell 108 475-487.

Niki T, Takahashi-Niki K, Taira T, Iguchi-Ariga SM \& Ariga H 2003 DJBP: a novel DJ-1-binding protein, negatively regulates the androgen receptor by recruiting histone deacetylase complex, and DJ-1 antagonizes this inhibition by abrogation of this complex. Molecular Cancer Research 1 247-261.

Nishida T \& Yasuda H 2002 PIAS1 and PIASxalpha function as SUMO-E3 ligases toward androgen receptor and repress androgen receptor-dependent transcription. Journal of Biological Chemistry 277 41311-41317.
Paez J \& Sellers WR 2003 PI3K/PTEN/AKT pathway. A critical mediator of oncogenic signaling. Cancer Treatment and Research 115 145-167.

Palvimo JJ, Reinikainen P, Ikonen T, Kallio PJ, Moilanen A \& Janne OA 1996 Mutual transcriptional interference between RelA and androgen receptor. Journal of Biological Chemistry 271 24151-24156.

Perinchery G, Sasaki M, Angan A, Kumar V, Carroll P \& Dahiya R 2000 Deletion of Y-chromosome specific genes in human prostate cancer. Journal of Urology 163 1339-1342.

Petre CE, Wetherill YB, Danielsen M \& Knudsen KE 2002 Cyclin D1: mechanism and consequence of androgen receptor co-repressor activity. Journal of Biological Chemistry 277 2207-2215.

Petre-Draviam CE, Cook SL, Burd CJ, Marshall TW, Wetherill YB \& Knudsen KE 2003 Specificity of cyclin D1 for androgen receptor regulation. Cancer Research 63 4903-4913.

Petre-Draviam CE, Williams EB, Burd CJ, Gladden A, Moghadam H, Meller J, Diehl JA \& Knudsen KE 2004 A central domain of cyclin D1 mediates nuclear receptor co-repressor activity. Oncogene 24 431-444.

Powzaniuk M, McElwee-Witmer S, Vogel RL, Hayami T, Rutledge SJ, Chen F, Harada S, Schmidt A, Rodan GA, Freedman LP et al. 2004 The LATS2/KPM tumor suppressor is a negative regulator of the androgen receptor. Molecular Endocrinology 18 2011-2023.

Reutens AT, Fu M, Wang C, Albanese C, McPhaul MJ, Sun Z, Balk SP, Janne OA, Palvimo JJ \& Pestell RG 2001 Cyclin D1 binds the androgen receptor and regulates hormone-dependent signaling in a p300/CBP-associated factor (P/CAF)-dependent manner. Molecular Endocrinology 15 797-811.

Rigas AC, Ozanne DM, Neal DE \& Robson CN 2003 The scaffolding protein RACK1 interacts with androgen receptor and promotes cross-talk through a protein kinase C signaling pathway. Journal of Biological Chemistry 278 46087-46093.

Salesi N, Carlini P, Ruggeri EM, Ferretti G, Bria E \& Cognetti F 2005 Prostate cancer: the role of hormonal therapy. Journal of Experimental and Clinical Cancer Research 24 175-180.

Schmidt D \& Muller S 2003 PIAS/SUMO: new partners in transcriptional regulation. Cellular and Molecular Life Sciences 60 2561-2574.

Schrantz N, da Silva Correia J, Fowler B, Ge Q, Sun Z \& Bokoch GM 2004 Mechanism of p21-activated kinase 6-mediated inhibition of androgen receptor signaling. Journal of Biological Chemistry 279 1922-1931.

Sengupta N \& Seto E 2004 Regulation of histone deacetylase activities. Journal of Cellular Biochemistry 93 57-67.

Shang Y, Myers M \& Brown M 2002 Formation of the androgen receptor transcription complex. Molecular Cell 9 601-610. 
Sharma M \& Sun Z $20015^{\prime}$ TG3' interacting factor interacts with $\mathrm{Sin} 3 \mathrm{~A}$ and represses AR-mediated transcription. Molecular Endocrinology 15 1918-1928.

Sharma M, Zarnegar M, Li X, Lim B \& Sun Z 2000 Androgen receptor interacts with a novel MYST protein, HBO1. Journal of Biological Chemistry 275 35200-35208.

Shenk JL, Fisher CJ, Chen SY, Zhou XF, Tillman K \& Shemshedini L 2001 p53 represses androgen-induced transactivation of prostate-specific antigen by disrupting hAR amino- to carboxyl-terminal interaction. Journal of Biological Chemistry 276 38472-38479.

Shi XB, Nesslinger NJ, Deitch AD, Gumerlock PH \& deVere White RW 2002 Complex functions of mutant p53 alleles from human prostate cancer. Prostate 51 59-72.

Shi XB, Gandour-Edwards R, Beckett LA \& Deitch AD 2004 A modified yeast assay used on archival samples of localized prostate cancer tissue improves the detection of p53 abnormalities and increases their predictive value. BJU international 94 996-1002.

Shi S, Rui M, Han W, Wang Y, Qiu X, Ding P, Zhang P, Zhu $\mathrm{X}$, Zhang Y, Gan Q et al. 2005 CKLFSF2 is highly expressed in testis and can be secreted into the seminiferous tubules. International Journal of Biochemistry \& Cell Biology 37 1633-1640.

Shou J, Ross S, Koeppen H, de Sauvage FJ \& Gao WQ 2001 Dynamics of notch expression during murine prostate development and tumorigenesis. Cancer Research 61 7291-7297.

Silverstein RA \& Ekwall K 2005 Sin3: a flexible regulator of global gene expression and genome stability. Current Genetics 47 1-17.

Sommer S \& Fuqua SA 2001 Estrogen receptor and breast cancer. Seminars in Cancer Biology 11 339-352.

Song LN, Coghlan M \& Gelmann EP 2004 Antiandrogen effects of mifepristone on coactivator and corepressor interactions with the androgen receptor. Molecular Endocrinology 18 70-85.

Sweeney C, Li L, Shanmugam R, Bhat-Nakshatri P, Jayaprakasan V, Baldridge LA, Gardner T, Smith M, Nakshatri H \& Cheng L 2004 Nuclear factor-kappaB is constitutively activated in prostate cancer in vitro and is overexpressed in prostatic intraepithelial neoplasia and adenocarcinoma of the prostate. Clinical Cancer Research 10 5501-5507.

Taplin ME \& Balk SP 2004 Androgen receptor: a key molecule in the progression of prostate cancer to hormone independence. Journal of Cellular Biochemistry 91 483-490.

Tomlins SA, Rhodes DR, Perner S, Dhanasekaran SM, Mehra R, Sun XW, Varambally S, Cao X, Tchinda J, Kuefer R et al. 2005 Recurrent fusion of TMPRSS2 and ETS transcription factor genes in prostate cancer. Science 310 (5748) 644-648.

Trapman J \& Brinkmann AO 1996 The androgen receptor in prostate cancer. Pathology, Research and Practice 192 752-760.
Truica CI, Byers S \& Gelmann EP 2000 Beta-catenin affects androgen receptor transcriptional activity and ligand specificity. Cancer Research 60 4709-4713.

Tsui KH, Chang PL, Lin HT \& Juang HH 2004 Downregulation of the prostate specific antigen promoter by $\mathrm{p} 53$ in human prostate cancer cells. Journal of Urology 172 2035-2039.

Urnov FD \& Wolffe AP 2001 Chromatin remodeling and transcriptional activation: the cast (in order of appearance). Oncogene 20 2991-3006.

Verrijdt G, Haelens A \& Claessens F 2003 Selective DNA recognition by the androgen receptor as a mechanism for hormone-specific regulation of gene expression. Molecular Genetics and Metabolism 78 (3) 175-185.

Wang X, Yang Y, Guo X, Sampson ER, Hsu CL, Tsai MY, Yeh S, Wu G, Guo Y \& Chang C 2002 Suppression of androgen receptor transactivation by Pyk2 via interaction and phosphorylation of the ARA55 coregulator. Journal of Biological Chemistry 277 15426-15431.

Wang S, Gao J, Lei Q, Rozengurt N, Pritchard C, Jiao J, Thomas GV, Li G, Roy-Burman P, Nelson PS et al. 2003 Prostate-specific deletion of the murine Pten tumor suppressor gene leads to metastatic prostate cancer. Cancer Cell 4 209-221.

Wang L, Lin HK, Hu YC, Xie S, Yang L \& Chang C $2004 a$ Suppression of androgen receptor-mediated transactivation and cell growth by the glycogen synthase kinase 3 beta in prostate cells. Journal of Biological Chemistry 279 32444-32452.

Wang L, Hsu CL, Ni J, Wang PH, Yeh S, Keng P \& Chang C $2004 b$ Human checkpoint protein hRad9 functions as a negative coregulator to repress androgen receptor transactivation in prostate cancer cells. Molecular and Cell Biology 24 2202-2213.

Wen YD, Perissi V, Staszewski LM, Yang WM, Krones A, Glass CK, Rosenfeld MG \& Seto E 2000 The histone deacetylase-3 complex contains nuclear receptor corepressors. PNAS 97 7202-7207.

Wilson JD 1996 Role of dihydrotestosterone in androgen action. Prostate Supplement 6 88-92.

Xia X, Lessor TJ, Zhang Y, Woodford N \& Hamburger AW 2001 Analysis of the expression pattern of Ebp1, an ErbB3-binding protein. Biochemical and Biophysical Research Communications 289 240-244.

Yang F, Li X, Sharma M, Zarnegar M, Lim B \& Sun Z 2001 Androgen receptor specifically interacts with a novel p21activated kinase, PAK6. Journal of Biological Chemistry 276 15345-15353.

Yoon HG \& Wong J 2005 The corepressors SMRT and $\mathrm{N}-\mathrm{CoR}$ are involved in agonist- and antagonist-regulated transcription by androgen receptor. Molecular Endocrinology 5 1048-1060.

Yoon HG, Chan DW, Huang ZQ, Li J, Fondell JD, Qin J \& Wong J 2003 Purification and functional 
characterization of the human N-CoR complex: the roles of HDAC3, TBL1 and TBLR1. EMBO Journal 22 1336-1346.

Yu X, Li P, Roeder RG \& Wang Z 2001 Inhibition of androgen receptor-mediated transcription by aminoterminal enhancer of split. Molecular and Cell Biology 21 4614-4625.

Yuan X, Lu ML, Li T \& Balk SP 2001 SRY interacts with and negatively regulates androgen receptor transcriptional activity. Journal of Biological Chemistry 276 46647-46654.

Zhang Y, Fondell JD, Wang Q, Xia X, Cheng A, Lu ML \& Hamburger AW 2002 Repression of androgen receptor mediated transcription by the ErbB-3 binding protein, Ebp1. Oncogene 21 5609-5618.

Zhang Y, Yang Y, Yeh S \& Chang C 2004 ARA67/PAT1 functions as a repressor to suppress androgen receptor transactivation. Molecular and Cell Biology 24 1044-1057.

Zhang Y, Akinmade D \& Hamburger AW 2005a The ErbB3 binding protein Ebp1 interacts with Sin3A to repress E2F1 and AR-mediated transcription. Nucleic Acids Research 33 6024-6033.
Zhang Y, Wang XW, Jelovac D, Nakanishi T, Yu MH, Akinmade D, Goloubeva O, Ross DD, Brodie A \& Hamburger AW 2005b The ErbB3-binding protein Ebp1 suppresses androgen receptor-mediated gene transcription and tumorigenesis of prostate cancer cells. PNAS $\mathbf{1 0 2}$ 9890-9895.

Zhou ZX, Sar M, Simental JA, Lane MV \& Wilson EM 1994 A ligand-dependent bipartite nuclear targeting signal in the human androgen receptor. Requirement for the DNAbinding domain and modulation by NH2-terminal and carboxyl-terminal sequences. Journal of Biological Chemistry 269 13115-13123.

Zhu P, Baek SH, Bourk EM, Ohgi KA, Garcia-Bassets I, Sanjo H, Akira S, Kotol PF, Glass CK, Rosenfeld MG et al. 2006 Macrophage/cancer cell interactions mediate hormone resistance by a nuclear receptor derepression pathway. Cell 124 615-629.

Zwijsen RM, Buckle RS, Hijmans EM, Loomans CJ \& Bernards R 1998 Ligand-independent recruitment of steroid receptor coactivators to estrogen receptor by cyclin D1. Genes and Development 12 3488-3498. 